\title{
Potential of predatory Neotropical ladybirds and minute pirate bug on strawberry aphid
}

\author{
NATALIA FRANCESENA ${ }^{1}$, MARGARITA ROCCA ${ }^{1}$, ESTEFANÍA \\ RIZZO $^{2}$, JOEL D. ARNEODO ${ }^{3}$ and NANCY M. GRECO ${ }^{1,4}$ \\ ${ }^{1}$ CEPAVE (CONICET - UNLP), Boulevard 120, s/n, 60 y 64, La Plata (CP 1900), Buenos Aires, Argentina \\ ${ }^{2}$ IMBIV (CONICET-UNC) (FCEFyN), Av. Velez Sarsfield, 1611, Córdoba (CP 5000), Argentina \\ ${ }^{3}$ IMyZA (INTA)/IABiMo (CONICET-INTA), Nicolas Repetto y de los Reseros, s/n, Hurlingham (CP 1868), Buenos Aires, Argentina \\ ${ }^{4} \mathrm{CIC}$, Calle 526, s/n, 10 y 11s/n, La Plata (CP 1900), Buenos Aires, Argentina
}

Manuscript received on September 24, 2018; accepted for publication on December 30, 2018

\begin{abstract}
How to cite: FRANCESENA N, ROCCA M, RIZZO E, ARNEODO JD AND GRECO NM. 2019. Potential of predatory Neotropical ladybirds and minute pirate bug on strawberry aphid. An Acad Bras Cienc 91: e20181001. DOI 10.1590/0001-3765201920181001.
\end{abstract}

\begin{abstract}
Laboratory trials were performed to determine the impact of three Neotropical predatory coccinellids (Cycloneda sanguinea, Eriopis connexa and Coleomegilla quadrifasciata) and a minute pirate bug (Orius insidiosus) on Chaetosiphon fragaefolii, an important strawberry aphid pest. The predation on $C$. fragaefolii nymphs and adults, as well as the time to the first attack of all predators were compared with predation on Aphis gossypii. Predator preferences for prey and aphid defensive behavior were also evaluated. Moreover, the effect of coccinellids on C. fragaefolii population growth was assessed in experimental greenhouse conditions. The predation rate varied among predators, being significantly lower for O. insidiosus than for the coccinellids. Consumption was higher on A. gossypii than on C. fragaefolii, regardless of the aphids developmental stage. The time to the first attack of all predators was longer in the presence of $C$. fragaefolii. Walking away and cornicle secretion were the most common antipredator behaviors of aphid against coccinellids and $O$. insidiosus, respectively. Coccinellids preferred $A$. gossypii over $C$. fragaefolii, while $O$. insidiosus showed indifference. Cycloneda sanguinea and $E$. connexa exhibited the highest suppression effect on the growth rate of $C$. fragaefolii. Thus, the four predators evaluated could contribute to reduce strawberry aphid populations, especially $C$. sanguinea and E. connexa.
\end{abstract}

Key words: Behavior, Biological control, Chaetosiphon fragaefolii, Fragaria $\mathrm{x}$ ananassa, Predation rate, Coccinellids.

\section{INTRODUCTION}

Aphids are important worldwide pests of strawberries, Fragaria $x$ ananassa Duchesne (Rosales: Rosaceae) (Rabasse et al. 2001, Thompson et al. 2003, Rondon et al. 2005). In Argentina and other countries (Cross et

Correspondence to: Nancy M. Greco

E-mail: ngreco@cepave.edu.ar

ORCid: https://orcid.org/0000-0003-3968-6604 al. 2001, Bernardi et al. 2013), the strawberry aphid Chaetosiphon fragaefolii Cockerell, as well as Aphis gossypii Glover and Macrosiphum euphorbiae Thomas (Hemiptera: Aphididae) are commonly found on strawberry (Cédola and Greco 2010, Cingolani and Greco 2018). Chaetosiphon fragaefolii is a vector of Strawberry mild yellow edge virus (SMYEV), Strawberry crinkle virus (SCV) and Strawberry mottle virus (SMoV). The 
latter is also transmitted by A. gossypii (Krczal 1982, Martin and Tzanetakis 2006, Tzanetakis and Martin 2013, Dughetti et al. 2017). In Argentina, the most frequently used method for aphids control in strawberry fields involves the regular use of broad spectrum insecticides. The development of alternative control strategies, as biological control, is important for more sustainable crop production.

The augmentative and conservation biological control requires knowledge about the relative potential of native or established agents. Parasitoids and predators are common natural enemies of aphids, so they are used for the biological control of agricultural pests in several countries (van Lenteren 2012). Different parasitoid species belonging to the genera Aphidius, Aphelinus, Praon and Lysiphlebus attack $A$. gossypii in strawberry crops. While high parasitism occurs on $A$. gossypii in strawberry, a very low parasitism by Hymenoptera parasitoids has been recorded on C. fragaefolii around the world (Oatman et al. 1983, Rondon and Cantliffe 2004, Cingolani and Greco 2018). Therefore, other mortality factors such as predation deserve more attention for the latter aphid species. Among aphid predators, coccinellids have the highest biocontrol potential (Hodek and Evans 2012), so they are widely used in pest management (van Lenteren 2012). Other natural enemies present in the crops, like predatory bugs of the genus Orius (Hemiptera: Anthocoridae), may also contribute to reduce aphid populations (Cross et al. 2001). These omnivorous insects, which are used worldwide for the control of thrips, can also attack aphids, whiteflies and mites, among other arthropods (Coll and Ridgeway 1995, Mendes et al. 2002, Rondon et al. 2004, Bonte et al. 2015).

The ladybirds Cycloneda sanguinea L., Eriopis connexa Germar and Coleomegilla quadrifasciata Schöenherr (Coleoptera: Coccinellidae), as well as the minute pirate bug Orius insidiosus (Say) are Neotropical predators, naturally occurring in horticultural crops around La Plata, Buenos Aires,
Argentina (Carrizo et al. 1999, Olivo et al. 2015, Rocca et al. 2017), such as sweet pepper, eggplant, tomato and leaf vegetables. In general, the predation rate is influenced by the type of prey offered (Mendes et al. 2002, Rondon et al. 2004, Desneux and O'Neil 2008). These coccinellids consume different aphid species, including A. gossypii, and $C$. quadrifasciata is even more polyphagous consuming other types of prey or also pollen (Noda et al. 2002, Isikber and Copland 2002, Isikber 2005, Hodek and Evans 2012). The predation of $O$. insidiosus on A. gossypii and other aphid species has been also reported (Lattin 2000, Mendes et al. 2002, Rondon and Cantliffe 2004); however, up to now there are no reports of predation of any of the above mentioned predators on $C$. fragaefolii.

The predator ability to search for different preys can determine a differential rate of consumption (Isenhour and Yeargan 1981, Evans 2003). Different prey species, prey sizes or prey developmental stages, as well as the presence of specific defensive mechanisms in aphids (Butler and O'Neil 2006, Nelson 2007, Barry and Ohno 2016) could affect predation capacity. The defensive responses of aphids to predators include dropping from the plant, kicking, or walking away if an appendage is grasped, and attacking predators with substances secreted from the cornicles (Hagen et al. 1999). The pea aphid Acyrthosiphon pisum (Harris) responds to the presence of predators by walking away or dropping off the plant (Losey and Denno 1998). Aulacorthum solani (Kaltenbach) drops from the sweet pepper plant in the presence of natural enemies (Rocca and Messelink 2017) and the soybean aphid Aphis glycines (Matsumura) produces exudates when attacked by $O$. insidiosus (Butler and O’Neil 2006).

Our initial hypothesis is that the rate of consumption of aphidophagous predators would be higher than that of generalist predators, and that these latter would not show preference among aphid species. The aims of this study were: 1) to estimate 
the predation rate of coccinellids and $O$. insidiosus on $C$. fragaefolii; 2) to compare the predation rate of the different predators on C. fragaefolli and $A$. gossypii; 3) to measure the time to the first attack of each predator against each prey species; 4) to identify the aphid antipredator behaviors; 5) to evaluate the preference of the different predators for each aphid species; 6) to evaluate the population growth of $C$. fragaefolii in presence of coccinellids in strawberry.

The results of this study will be very useful to implement IPM strategies for pests in strawberry crop (Greco et al. 2011) in order to obtain premium pesticide-free strawberries.

\section{MATERIALS AND METHODS}

The insect rearing and all laboratory experiments were carried out under controlled environmental conditions $\left(25 \pm 2^{\circ} \mathrm{C}, 70 \pm 5 \% \mathrm{HR}\right.$ and 16:8 L:D).

\section{INSECT REARING}

Aphids (C. fragaefolii and A. gossypii) and coccinellids (C. sanguinea, E. connexa and $C$. quadrifasciata) were collected from organic greenhouse crops in La Plata, Argentina (34 $\left.56^{\circ} 04^{\prime \prime} \mathrm{S} 58^{\circ} 10^{\prime} 14^{\prime \prime} \mathrm{W}\right)$ and kept in quarantine. The progeny of each insect species was used to start the laboratory colonies.

Aphids were reared in plastic cylinders $(6 \mathrm{~cm}$ diameter x $5 \mathrm{~cm}$ high) on strawberry leaf discs adaxially embedded in water agar (1\%). The plastic cylinders were placed upside-down, thus ensuring that the abaxial side of the leaf discs (where the aphids feed) faced downwards as they would on intact plants. Ventilation was possible through a hole in the lid covered with insect gauze $(80 \mu \mathrm{m}$ mesh) and because the boxes were placed on a wire gridwall shelf.

The coccinellids, adults and larvae, were reared separately in ventilated plastic cages $(15 \mathrm{~cm}$ high x $15 \mathrm{~cm}$ long x $25 \mathrm{~cm}$ wide) containing Triticum aestivum seedlings (standard substrate fertile soil and perlite $1: 1 \mathrm{v} / \mathrm{v}$ ) infested with Rhopalosiphum padi L. (Hemiptera: Aphididae) and covered with voile. Ten individuals were placed in each plastic cage, and the proportion of adult female to male was $1: 1$. Seedlings were previously germinated in plastic pots (6 $\mathrm{cm}$ high and $4 \mathrm{~cm}$ diameter) with standard substrate (fertile soil and perlite 1:1 v/v) and infested with aphids at germination. Plants were maintained in ventilated plastic boxes $(13 \mathrm{~cm}$ high x $30 \mathrm{~cm}$ long x $23 \mathrm{~cm}$ wide) until more than $80 \%$ of each seedling was infested with aphids. Water was provided on a sponge inserted into an Eppendorf tube. For adults, the bottom of each container was lined with paper towel as an oviposition substrate. The maintenance of rearing conditions was done twice weekly and the paper towel was transferred to a new plastic box until the larvae hatched.

Orius insidiosus individuals were purchased from a commercial supplier (Brometán SRL, Argentina). These were reared according to the methodology proposed by Bueno (2000) and Bueno et al. (2006), in glass vials of 3 liters capacity, with a top hole covered with voile to allow ventilation. Crumpled paper strips were placed inside to provide shelters, together with green bean pods for oviposition and eggs of Ephestia kuehniella Zeller (Lepidoptera: Pyralidae) ad libitum as food. Twice a week the bean pods were removed from the oviposition glass vials and transferred to new vials for nymph hatching. These were fed ad libitum with frozen E. kuehniella eggs twice a week until maturity, when bean pods were incorporated for oviposition.

\section{LABORATORY EXPERIMENTS}

The experimental unit consisted of plastic cylinders ( $6 \mathrm{~cm}$ diameter x $5 \mathrm{~cm}$ high) sealed with parafilm, and containing a strawberry leaf embedded in water agar $(1 \%)$. A constant number of aphids and a recently mated female predator (a 4-5 weeks old coccinellid or a 5-7 days old $O$. insidiosus) starved 
for 24 hours were placed in each experimental unit. To evaluate predation rates, the treatments with coccinellids were: a) control (without predator); b) $1504^{\text {th }}$ instar $C$. fragaefolii nymphs; c) $1504^{\text {th }}$ instar $A$. gossypii nymphs; d) $100 C$. fragaefolii adults; e) $100 \mathrm{~A}$. gossypii adults. In the case of $O$. insidiosus the same treatments were conducted but the number of prey offered was 12 . Ten replications per treatment were performed. The initial number of aphids used in all treatments was based on similar experiments performed by other authors with $A$. gossypii as prey (Noda et al. 2002, Rondon et al. 2004). The variables recorded were: a) the number of prey alive after 24 hours, b) the time to the first attack (seconds), and c) the number of replicates in which antipredator behaviors (walking away and cornicle secretion) were observed. Predators and aphids behaviors were recorded by direct observation during the first 10 minutes of the experiment. The number of aphids consumed in $24 \mathrm{~h}$ was estimated as: (the initial number of aphids) - (the number of aphids alive after $24 \mathrm{~h}+$ the number of aphids dead by other causes). The mortality from other causes was due only to the fact that the aphids that left the leaf were trapped in the agar of the experimental unit. The predation rate was calculated using Abbott correction (Abbott 1925) as: (number of aphids alive in the control at the end of the assay - number of aphids alive in the treatment at the end of the assay) / (number of aphids alive in the control at the end of the assay) and analyzed with factorial ANOVA, with predator species, aphid species and developmental stage of aphids as factors. Data were arcsine transformed to meet the required assumptions of parametric statistical methods. Differences amongst treatments were tested using Tukey HSD method $(P<0.05)$. The time to the first attack was analyzed by factorial ANOVA, with the previously mentioned factors. The square-root transformation was used to meet parametric assumptions. The aphid behavior (walking away and cornicle secretion) was evaluated separately. The number of replicates in which antipredator behavior occurred was analyzed for both aphid species by a two-way (antipredator behavior and predator species) $\chi^{2}$ contingency test. The null hypothesis was that this behavior is independent of the predator species.

To evaluate predators preference, the experimental unit was similar to that in the previous experiment ( $c f$. below predation rate and predators and aphid behavior for more details). The treatments with coccinellids were: a) control (without predator); b) $75 \mathrm{C}$. fragaefolii and $75 \mathrm{~A}$. gossypii $4^{\text {th }}$ instar nymphs; c) $75 C$. fragaefolii and 75 A. gossypii adults. The same treatments were conducted with $O$. insidiosus but the total number of prey offered was 12 (6 C. fragaefolii and $6 \mathrm{~A}$. gossypii nymphs or adults). Ten replications per treatment were performed. Prey preference of predators was estimated using the Manly's index without replacement of prey (Manly 1974), according to the following formula: $a_{i}=\ln _{p i} / \sum_{i=1}^{m} p_{j}$; where $\alpha_{i}$ is a Manly's preference index for prey $i ; p_{i}$ and $p_{j}$ are the proportions of prey $i$ or $j$ alive at the end of the experiment (i.e. the number of prey $i$ or $j$ alive at the end of the experiment/the initial number of prey $i$ or $j$ ); $m$ is the number of types of prey. This index takes values between 0 and 1 . In this study, because two different preys were offered, $\alpha$ values $>0.5$ indicate preference and $\alpha$ values $<0.5$ rejection. The prey preference of each predator was analyzed estimating whether $\alpha_{i}$ and $\alpha_{j}$ values were significantly different from 0.5 using the two-tailed $t$ test for differences between an estimated mean and a hypothesized value.

\section{EXPERIMENTAL GREENHOUSE ASSAY}

The population growth of $C$. fragaefolii in presence of $C$. sanguinea, E. connexa and C. quadrifasciata in strawberry was estimated in an experimental greenhouse in December 2017. Strawberry plants (cv. Sweet Ann) were grown individually in 5-liter plastic pots with soil plus humus (50:50) under natural photoperiod (14:10 L:D). Each experimental unit consisted of one plant with five leaves placed 
in the center of a voile cage $(30 \mathrm{~cm}$ high $\mathrm{x} 30 \mathrm{~cm}$ long x $30 \mathrm{~cm}$ wide). The average temperature and relative humidity during the experiment was $21.4^{\circ} \mathrm{C}$ (range $12.4-30.3^{\circ} \mathrm{C}$ ) and $48.9 \%$ (range $14.2-88.6 \%$ ) respectively.

Plants were infested with 20 C. fragaefolii nymphs (mixed-instars). After 7 days, the number of aphids in each plant was counted and approximately 100 individuals were taken as initial density, removing the rest of them. Each experimental unit was distributed within the greenhouse using a randomized block design, and natural enemies were added to achieve each of the following treatments: a) Control (without predator); b) one female of $C$. sanguinea; c) one female of $E$. connexa; d) one female of $C$. quadrifasciata. All females were mated and age ranged between 4-5 weeks. Each treatment was replicated ten times. After 7 days, the number of aphids was counted in order to estimate the growth rate of $C$. fragaefolii in the different treatments.

Assuming that the growth is exponential, the following formula was used to estimate the growth rate (r): $\mathrm{r}=\ln \left(\mathrm{N}_{\mathrm{t}} / \mathrm{N}_{0}\right) / \Delta \mathrm{t}$, where $\mathrm{N}_{\mathrm{t}}$ : number of aphids at the end of the experiment; $\mathrm{N}_{0}$ : number of aphids at the beginning of the experiment; $\Delta \mathrm{t}$ : 7 days. The data were analyzed using KruskalWallis test. Subsequently, multiple comparisons were made of the average rank for each pair of groups, calculating the z-average value for each comparison, and the corresponding probability (corrected for the number of comparisons) for a two-tailed significance test.

\section{RESULTS}

\section{LABORATORY EXPERIMENTS}

\section{Predation rate}

The predation rate varied depending on predator species and also the aphid species. Significant interaction was found between predators and aphids species (Table I). O. insidiosus predation rate was significantly smaller than that of the three coccinellids. The predation rate by all species of predators on C. fragaefolii was lower than on $A$. gossypii. All predators consumed the aphid nymphs and adults at similar rates (Table II).

Time to the first attack

Every predator took the same time to attack nymphs and adults but the time to the first attack varied depending on prey and predator species. There was no significant interaction between any of the three variables (predator, prey and developmental stage of the prey) evaluated (Table III). The time to the first attack by all predators was consistently higher when $C$. fragaefolii was the prey. Regarding this parameter, no significant differences were observed among predators on $C$. fragaefolii nymphs. However, O. insidiosus was faster than C. sanguinea and $C$. quadrifasciata in attacking $C$. fragaefolii adults. In presence of $A$. gossypii, $O$. insidiosus and C. sanguinea were faster than C. quadrifasciata in attacking nymphs and $O$. insidiosus was faster than $C$. quadrifasciata in attacking adults. The rest of the evaluated predator/prey interactions showed statistically overlapping results (Table IV).

TABLE I

Analysis of variance of the effects of predator species, prey species and development stage on the predation rate of Cycloneda sanguinea, Eriopis connexa, Coleomegilla quadrifasciata and Orius insidiosus on Chaetosiphon fragaefolii and Aphis gossypii preys.

\begin{tabular}{cccc}
\hline Source of variation & $\boldsymbol{d} \boldsymbol{f}$ & $\boldsymbol{F}$ & $\boldsymbol{P}$ \\
\hline Predator & 3 & 13.7 & $<0.001$ \\
Prey & 1 & 69.9 & $<0.001$ \\
Development stage of prey & 1 & 0.2 & 0.694 \\
Predator * Prey & 3 & 4.9 & $<0.001$ \\
Predator * Development stage & 3 & 0.3 & 0.802 \\
$\begin{array}{c}\text { of prey } \\
\text { Prey * Development stage of prey }\end{array}$ & 1 & 0.0 & 0.955 \\
Predator * Prey * Development & 3 & 1.0 & 0.395 \\
stage of prey & & & \\
Error & 144 & & \\
\hline
\end{tabular}


TABLE II

Predation rate and number of aphids consumed (in parentheses) in $24 \mathrm{~h}$ by different predator species. The data correspond to the means \pm the standard error.

\begin{tabular}{|c|c|c|c|c|}
\hline \multirow[t]{2}{*}{ Predators } & \multicolumn{2}{|c|}{ Chaetosiphon fragaefolii } & \multicolumn{2}{|c|}{ Aphis gossypii } \\
\hline & nymphs & adults & nymphs & adults \\
\hline Cycloneda sanguinea & $\begin{array}{c}0.38 \pm 0.05 \mathbf{a} \\
(57.2 \pm 7.1)\end{array}$ & $\begin{array}{c}0.37 \pm 0.08 \mathbf{a} \\
(37 \pm 7.8)\end{array}$ & $\begin{array}{l}0.84 \pm 0.02 \mathbf{c} \\
(126.6 \pm 3.1)\end{array}$ & $\begin{array}{c}0.86 \pm 0.04 \mathbf{c} \\
(85.8 \pm 3.9)\end{array}$ \\
\hline Eriopis connexa & $\begin{array}{l}0.46 \pm 0.08 \mathbf{a} \\
(69.8 \pm 12.5)\end{array}$ & $\begin{array}{l}0.46 \pm 0.10 \mathbf{a} \\
(46.4 \pm 9.9)\end{array}$ & $\begin{array}{c}0.67 \pm 0.05 \mathbf{c} \\
(101 \pm 8.4)\end{array}$ & $\begin{array}{c}0.81 \pm 0.04 \mathbf{c} \\
(80.6 \pm 4.1)\end{array}$ \\
\hline Coleomegilla quadrifasciata & $\begin{array}{l}0.45 \pm 0.07 \mathbf{a} \\
(67.7 \pm 10.9)\end{array}$ & $\begin{array}{c}0.46 \pm 0.09 \mathbf{a} \\
(46 \pm 9.2)\end{array}$ & $\begin{array}{l}0.61 \pm 0.04 \mathbf{c} \\
(92.6 \pm 6.9)\end{array}$ & $\begin{array}{c}0.6 \pm 0.05 \mathbf{c} \\
(60 \pm 4.9)\end{array}$ \\
\hline Orius insidiosus & $\begin{array}{c}0.21 \pm 0.04 \mathbf{b} \\
(2.3 \pm 0.57)\end{array}$ & $\begin{array}{c}0.28 \pm 0.06 \mathbf{b} \\
\quad(3 \pm 0.53)\end{array}$ & $\begin{array}{c}0.50 \pm 0.08 \mathbf{d} \\
(5.6 \pm 0.74)\end{array}$ & $\begin{array}{c}0.39 \pm 0.08 \mathbf{d} \\
\quad(4 \pm 0.83)\end{array}$ \\
\hline
\end{tabular}

Within and between the columns, different letters denote significant differences among treatments $(P \leq 0.05)$.

TABLE III

Analysis of variance of the effects of predator species, prey species and development stage on the time of the first attack of Cycloneda sanguinea, Eriopis connexa, Coleomegilla quadrifasciata and Orius insidiosus.

\begin{tabular}{cccc}
\hline Source of variation & $\boldsymbol{d f}$ & $\boldsymbol{F}$ & $\boldsymbol{P}$ \\
\hline Predator & 3 & 18.50 & $<0.001$ \\
Prey & 1 & 35.45 & $<0.001$ \\
Development stage of prey & 1 & 2.63 & 0.106 \\
Predator * Prey & 3 & 1.88 & 0.134 \\
Predator * Development stage & 3 & 2.44 & 0.097 \\
$\begin{array}{c}\text { of prey } \\
\text { Prey * Development stage of prey }\end{array}$ & 1 & 0.75 & 0.385 \\
Predator * Prey * Development & 3 & 0.92 & 0.428 \\
stage of prey & & & \\
Error & 144 & & \\
\hline
\end{tabular}

\section{Aphid antipredator behavior}

In relation to antipredator behavior, the frequency of walking away (i.e. number of replicates in which this behavior was recorded) was similar for both aphid species $\left(\chi^{2}=2.20, \mathrm{df}=1, P=0.13\right)($ Fig. 1a) and dependent on the predator species $\left(\chi^{2}=28.49\right.$; $\mathrm{df}=3, P<0.0001)$. Neither aphid species showed this behavior in the presence of $O$. insidiosus. In contrast, the highest frequency was recorded in the presence of $C$. sanguinea (Fig. 1b). The frequency of cornicle secretion (i.e. number of replicates in which this behavior was recorded) was different between the two aphid species $\left(\chi^{2}=5.83\right.$, df $=1$, $P=0.016$ ) being higher for $A$. gossypii (Fig. 1a). Moreover, it was more frequent in presence of $O$. insidiosus than in the presence of coccinellids $\left(\chi^{2}=\right.$ 29.23, $\mathrm{df}=3, P<0.0001)($ Fig. 1c).

\section{Preference of predators for aphids}

In the preference assays, all coccinellids preferred to feed on both nymphs and adults of $A$. gossypii (C. sanguinea: $t_{\text {nymphs }}=9.81, \mathrm{df}=9, P<0.0001$ and $t_{\text {adults }}=4.90, \mathrm{df}=9, P<0.0001 ;$ E. connexa: $t_{\text {nymphs }}$ $=7.50, \mathrm{df}=9, P<0.0001$ and $t_{\text {adults }}=6.70, \mathrm{df}=9, P$ $<0.0001$; and C. quadrifasciata: $t_{\text {nymphs }}=4.96, \mathrm{df}=$ $9, P<0.0001$ and $t_{\text {adults }}=5.88, \mathrm{df}=9, P<0.0001$ ). Instead, $O$. insidiosus showed indifference for both aphid species $\left(t_{\text {nymphs }}=0.97, \mathrm{df}=9, P=0.35\right.$ and $t$ adults $=0.25, \mathrm{df}=9, P=0.80)($ Fig. $2 \mathrm{a}, \mathrm{b})$.

\section{EXPERIMENTAL GREENHOUSE ASSAY}

The growth rate of $C$. fragaefolii was significantly lower in presence of $C$. sanguinea and $E$. connexa than in presence of $C$. quadrifasciata or in the absence of predators (control treatment) $\left(H_{(3, \mathrm{~N}=38)}=\right.$ 27.93, $P<0.0001$ ) (Fig. 3). 
TABLE IV

Time (seconds) to the first attack by different predator species in presence of aphids species. The data correspond to the means \pm the standard error.

\begin{tabular}{ccccc}
\hline \multirow{2}{*}{ Predators } & \multicolumn{3}{c}{ Chaetosiphon fragaefolii } & \multicolumn{2}{c}{ Aphis gossypii } \\
\cline { 2 - 5 } & nymphs & adults & nymphs & adults \\
\hline Cycloneda sanguinea & $460.10( \pm 75.39) \mathbf{a A}$ & $391.40( \pm 79.61) \mathbf{a A}$ & $77.10( \pm 21.33) \mathbf{b A}$ & $165( \pm 75.19) \mathbf{b A B}$ \\
Eriopis connexa & $410.10( \pm 68.38) \mathbf{a A}$ & $304.50 \pm(70.81) \mathbf{a A B}$ & $203.40( \pm 62.06) \mathbf{b A B}$ & $185( \pm 56.32) \mathbf{b A B}$ \\
Coleomegilla quadrifasciata & $439.90( \pm 68.75) \mathbf{a A}$ & $549.60( \pm 49.43) \mathbf{a A}$ & $431.20( \pm 86.63) \mathbf{b B}$ & $339.70( \pm 68.54) \mathbf{b A}$ \\
Orius insidiosus & $275.80( \pm 47.69) \mathbf{a A}$ & $111.20( \pm 55.08) \mathbf{a B}$ & $78.70( \pm 22.38) \mathbf{b A}$ & $41.80( \pm 26.97) \mathbf{b B}$
\end{tabular}

Different lowercase letters between columns and different uppercase letters within columns denote significant differences among treatments $(P \leq 0.05)$.

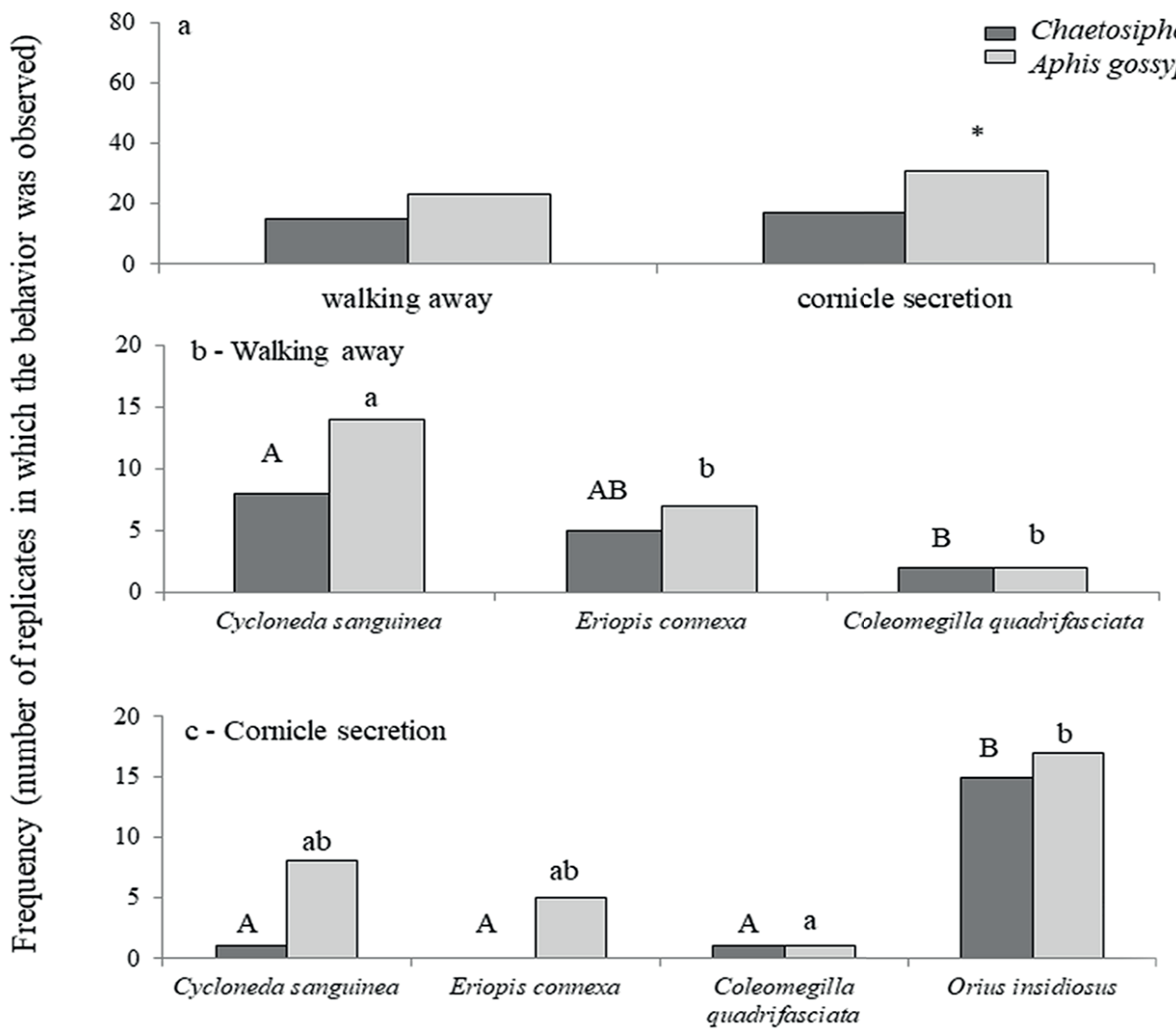

Figure 1 - Results of antipredator behavior assay showing the frequency (number of replicates) of a) total walking away and cornicle secretion behaviors, b) walking away and c) cornicle secretion behaviors of aphid species in the presence of different predator species. Asterisk indicates significant differences between aphid species for each behavior; uppercase letters and lowercase letters show significant differences for $C$. fragaefolii and A. gossypii, respectively, in the presence of different predator species $(P$ $<0.05)$. 


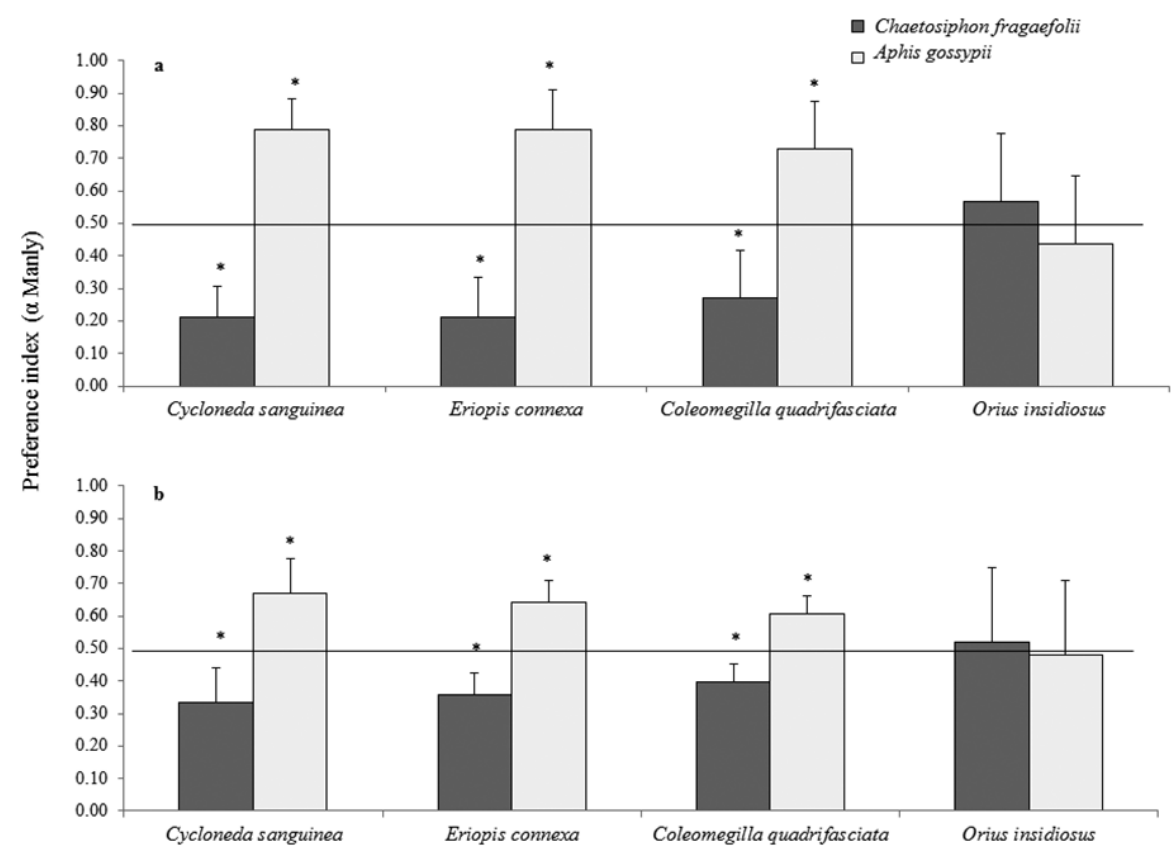

Figure 2 - Manly's index values of preference assay for different predator species on a) nymphs and b) adults of $C$. fragaefolii and A. gossypii. Line indicates the reference value of 0.50 that indicates indifference, values $>0.5$ preference and values $<0.5$ rejection. Asterisk indicates significant differences from 0.5 using the two-tailed t test for a single sample.

\section{DISCUSSION}

In this study, we found that all four predators fed on $C$. fragaefolii, but the predation rate was lower on this species than on $A$. gossypii. Other studies had reported predation rates of $A$. gossypii by coccinellids (Noda et al. 2002, Rondon et al. 2005, Isikber 2005). Noda et al. 2002 found that E. connexa and C. quadrifasciata consumed 31 and $34.5 \mathrm{~A}$. gossypii adults per day (44 and 49\% of the offered preys, respectively), less than shown in the present study. However, similar predation rates by $C$. sanguinea on $A$. gossypii were observed by Isikber (2005). Experimental conditions could affect the consumption of the same prey, e.g. the host plant and the arrangement of the experimental unit. So, in order to make accurate comparisons, the different predator/prey interactions under study should be evaluated in the same type of experiment. The preference experiments also contribute to determine differential predation on distinct prey species. The preference of coccinellids for $A$. gossypii found in this study agrees with previous reports involving Propylea dissecta Mulsant (Coleoptera: Coccinellidae) and seven aphid species (Pervez and Omkar 2003).

The predation rate of $O$. insidiosus was significantly lower than that of coccinellids, and this predator showed indifference against both developmental stage and aphid species. Minute pirate bugs are able to complete their whole life cycle (including reproduction) feeding on aphids (Mendes et al. 2002), but thrips are their preferred prey (Bonte et al. 2015, Butler and O'Neil 2008, Desneux and O'Neil 2008). Also, this predator preferentially fed on the two spotted spider mite Tetranychus urticae Koch rather than on the cotton aphid (Rondon et al. 2004). The predator consumption could be related to prey nutritional quality (Nagai 1991) and/or defensive response (Butler and O’Neil 2006), among other factors. 


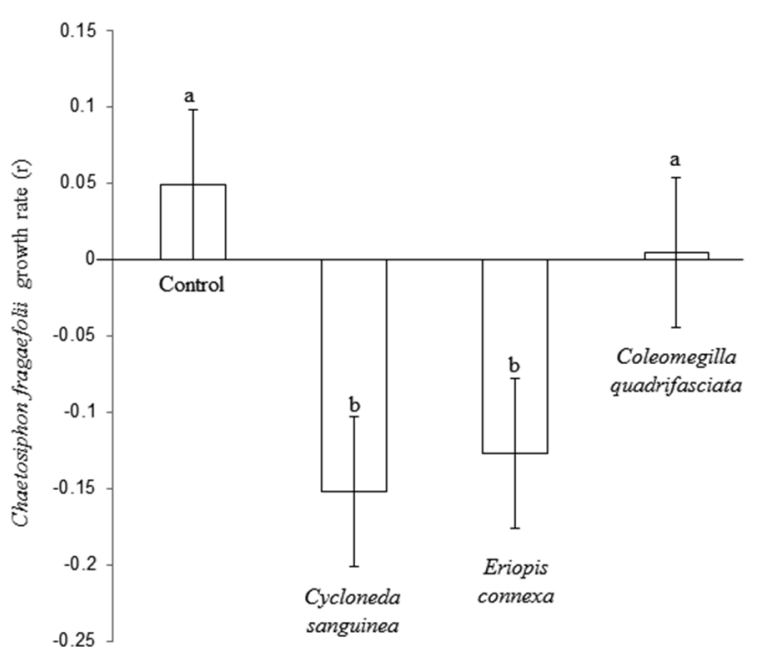

Figure 3 - Results of experimental greenhouse assay showing the reduction in the population growth of $C$. fragaefolii in the presence of $C$. sanguinea, E. connexa and C. quadrifasciata in strawberry plants. Different letters indicate significant differences $(P<0.05)$.

When given the choice, hemipteran predators prefer to attack highly mobile preys (Venzon et al. 2002). The effect of prey mobility on prey selection seems to be predator-specific (Eubanks and Denno 2000). In our study, C. fragaefolii and A. gossypii did not show the walking away behavior in the presence of O. insidiosus, and Butler and O'Neil (2008) also found that soybean aphids were sedentary when this predator approached them.

The time to the first attack of all predators was consistently higher when the prey was $C$. fragaefolii than when it was $A$. gossypii and, in general, $O$. insidiosus was faster than coccinellids in attacking both aphid species. The most recurrent antipredator behavior of both aphid species in the presence of $O$. insidiosus was cornicle secretion. This could be a response to the feeding mode of the predator, since bugs insert their beak into the host body, usually several times, to absorb the body contents. This behavior was also observed by other authors when $A$. gossypii was exposed to $O$. insidiosus (Butler and O'Neil 2008, Desneux and O'Neil 2008). In contrast, walking away was the most common aphid behavior in the presence of coccinellids. In all cases, the frequency of walking away increased in the presence of C. sanguinea, compared to other predators. Defensive behaviors of $C$. fragaefolii were generally less frequent than those of $A$. gossypii, so factors other than behavior are presumably involved in the differential predation on $C$. fragaefolii and A. gossypii. The body of $C$. fragaefolii is covered with conspicuous capitate hairs of unknown function which could be related to defensive mechanisms (Rondon and Cantliffe 2004).

Cycloneda sanguinea and E. connexa reduced significantly the rate of population increase of $C$. fragaefolii in experimental greenhouse conditions. Thus, these coccinellids could be regarded as effective biological control agents for this aphid in strawberry. Different genera of Coccinellidae (Rhyzobius, Adalia and Coleomegilla) were found attacking and consuming this aphid in the field (Dicker 1952, van Driesche and Hauschild 1987); however, this is the first report about the effect of ladybirds on its population growth rate.

Cycloneda sanguinea, E. connexa, C. quadrifasciata and $O$. insidiosus could all play a role in diminishing $C$. fragaefolii populations in strawberry crop, especially the former two species. The ascertained considerably different effect on the population growth of C. fragaefolii (Fig. 3) by Coleomegilla quadrifasciata could be related to the well known polinivory in the genus Coleomegilla (Hodek and Evans 2012). However, all the predators' efficiency to reduce $C$. fragaefolli populations in the field would presumably depend on its relative abundance in relation to that of $A$. gossypii. Results of this study may be used as a basis to explain specific predator-aphid interactions in strawberry crop.

Information about $C$. fragaefollii is scarce throughout the world and particularly in Neotropical region. Accordingly, these new findings about potential control agents are useful 
to design appropriate management strategies for these aphids.

\section{ACKNOWLEDGMENTS}

This study was supported by the National Agency for Promotion of Science and Technology of Argentina, grant PICT 2015-1427 and the Program of Incentives for Professors-Researchers of the National Ministry of Culture and Education of Argentina, grant N834.

\section{AUTHORS CONTRIBUTIONS}

Natalia Francesena performed all laboratory tests, she collaborated in the analysis of the data and in the writing of the manuscript. Margarita Rocca performed data analyzes, interpreted the results and collaborated in the writing of the manuscript. Estefanía Rizzo, carried out the insect rearing and collaborated in the laboratory assays. Joel Arneodo participated in the discussion of the results and in the writing of the manuscript. Nancy Greco carried out the planning of the essays and participated in the data analysis and interpretation and discussion of results, as well as in the writing of the manuscript. She also obtained the funds to carry out the investigation.

\section{REFERENCES}

ABBOTT WS. 1925. A Method of Computing the Effectiveness of an Insecticide. J Econ Entomol 18: 265-267.

BARRY A AND OHNO K. 2016. Cornicle secretions of Uroleucon nigrotuberculatum (Homoptera: Aphididae) as the last bullet against lady beetle larvae. Entomol Sci 19: 410-415.

BERNARDI D, ARAUJO ES, ZAWADNEAK MAC, BOTTON M, MOGOR AF AND GARCIA MS. 2013. Aphid Species and Population Dynamics Associated with Strawberry. Neotrop Entomol 42: 628-633.

BONTE J, DE HAUWERE L, CONLONG D AND DE CLERCQ P. 2015. Predation capacity, development and reproduction of the southern African flower bugs Orius thripoborus and Orius naivashae (Hemiptera: Anthocoridae) on various prey. Biol Control 86: 52-59.

BUENO VHP. 2000. Desenvolvimento e multiplicação de percevejos predadores do gênero Orius Wolff, in Controle biológico de pragas: produção massal e controle de qualidade, ed. by Bueno VHP, UFLA, Lavras, Brasil, p. 69-90.

BUENO VHP, MENDES SM AND CARVALHO LM. 2006. Evaluation of a rearing-method for the predator Orius insidiosus. Bull Insectology 59: 1-6.

BUTLER CD AND O'NEIL RJ. 2006. Defensive response of soybean aphid (Hemiptera: Aphididae) to predation by insidious flower bug (Hemiptera: Anthocoridae). Ann Entomol Soc Am 99: 317-320.

BUTLER CD AND O'NEIL RJ. 2008. Voracity and prey preference of insidious flower bug (Hemiptera: Anthocoridae) for immature stages of soybean aphid (Hemiptera: Aphididae) and soybean thrips (Thysanoptera: Thripidae). Environ Entomol 37: 964-972.

CARRIZO P, CARPINTERO D AND CÉDOLA C. 1999. Relevamiento preliminar de enemigos naturales de trips en flores de malezas en el área hortícola del Gran La Plata. Rev Fac Agron 19: 139-146.

CÉDOLA C AND GRECO N. 2010. Presence of the aphid, Chaetosiphon fragaefolii, on strawberry in Argentina. J Insect Sci 10: 1-9.

CINGOLANI MF AND GRECO N. 2018. Spatio-temporal variation of strawberry aphid populations and their parasitoid. Appl Entomol Zool 53: 205-214.

COLL M AND RIDGEWAY RL. 1995. Functional and numerical responses of Orius insidiosus (Heteroptera: Anthocoridae) to its prey in different vegetable crops. Ann Entomol Soc Am 88: 732-738.

CROSS JV, EASTERBROOK MA, CROOK AM, CROOK D, FITZGERALD JD, INNOCENZI PJ, JAY CN AND SOLOMON MG. 2001. Review: natural enemies and biocontrol of pests of strawberry in Northern and Central Europe. Biocontrol Sci Techn 11: 165-216.

DESNEUX N AND O'NEIL RJ. 2008. Potential of an alternative prey to disrupt predation of the generalist predator, Orius insidiosus, on the pest aphid, Aphis glycines, via short-term indirect interactions. Bull Entomol Res 98: 631-639.

DICKER GHL. 1952. Studies in population fluctuations of the strawberry aphid, Pentatrichopus fragaefolii (Cock.). 1. Enemies of the strawberry aphid. Ann Rept East Malling Res Sta for 1951 39: 166-168.

DUGHETTI AC, KIRSCHBAUM DS AND CONCI VC. 2017. Especies de virus y pulgones encontrados en cultivos de frutilla en Argentina. RIA 43: 36-50.

EUBANKS MD AND DENNO RF. 2000. Health food versus fast food: the effects of prey quality and mobility on prey selection by a generalist predator and indirect interactions among prey species. Ecol Entomol 25: 140-146.

EVANS EW. 2003. Searching and reproductive behaviour of female aphidophagous ladybirds (Coleoptera: Coccinellidae): a review. Eur J Entomol 100: 1-10.

GRECO NM, LILJESTHRÖM GG, GUGOLE OTTAVIANO MF, CLUIGT N, CINGOLANI MF, ZEMBO JC AND SÁNCHEZ NE. 2011. Pest management plan for Tetranychus urticae based on the natural occurrence 
of Neoseiulus californicus (Acari: Tetranychidae, Phytoseiidae) in strawberry. Int J Pest Manage 57: 299308.

HAGEN KS, MILLS NJ, GORDH G AND MC MURTY JA. 1999. Terrestrial arthropod predators of insect and mite pests, in Handbook of biological control, ed. by Bellows TS and Fisher TW, Academic Press, San Diego, USA, p. 383-503.

HODEK I AND EVANS EW. 2012. Food relationships, in Ecology and behaviour of the ladybird beetles, Hodek I, van Emden HF and Honek A (Eds), Wiley-Blackwell, Oxford, UK, p. 141-274.

ISENHOUR DJ AND YEARGAN KV. 1981. Interactive behavior of Orius insidiosus (Hem.: Anthocoridae) and Sericothrips variabilis (Thys.: Thripidae): predator searching strategies and prey escape tactics. Entomophaga 26: 213-220.

ISIKBER AA. 2005. Functional response of two coccinellid predators, Scymnus levaillanti and Cycloneda sanguinea, to the cotton aphid, Aphis gossypii. Turk J Agric For 29: 347-355.

ISIKBER AA AND COPLAND MJW. 2002. Effects of various aphid foods on Cycloneda sanguinea. Entomol Exp Appl 102: 9397.

KRCZAL H. 1982. Investigations on the biology of the strawberry aphids (Chaetosiphon fragaefolii), the most important vector of strawberry viruses in West Germany. Acta Hortic 129: 63-68.

LATTIN JD. 2000. Economic importance of minute pirate bugs (Anthocoridae), in Heteroptera of Economic Importance, ed. by Schoefer CWS and Panizzi AR, Florida, CRC Press, USA, p. 607-637.

LOSEY JE AND DENNO RF. 1998. The escape response of pea aphids to foliar-feeding predators factors affecting dropping behavior. Ecol Entomol 23: 53-61.

MANLY BFJ. 1974. A model for certain types of selection experiments. Biometrics 30: 281-294.

MARTIN RR AND TZANETAKIS IE. 2006. Characterization and recent advances in detection of strawberry viruses. Plant Dis 90: 384-396.

MENDES SM, BUENO VH, ARGOLO VM AND SILVEIRA LCP. 2002. Type of prey influences biology and consumption rate of Orius insidiosus (Say) (Hemiptera, Anthocoridae). Rev Bras Entomol 46: 99-103.

NAGAI K. 1991. Predatory characteristics of Orius sp. on Thrips palmi Karny, Tetranychus kanzawi Kishida, and Aphis gossypii Glover. Jap J Appl Ent and Zool 35: 269274.

NELSON EH. 2007. Predator avoidance behavior in the pea aphid: costs, frequency, and population consequences. Oecologia 151: 22-32.

NODA T, KIMURA Y, DE LÓPEZ MBR, DE EVERT MT AND PALACIO C. 2002. Potential of predatory natural enemies for biological control of sap-sucking insect pests in Paraguay. JARQ 36: 31-35.

OATMAN ER, TRUMBLE JT AND VOTH V. 1983. Composition and relative abundance of parasites associated with aphid populations on strawberry in Southern California. Environ Entomol 12: 1714-1717.

OLIVO VI, RODRÍGUEZ CA, COSCARÓN MC AND CORRONCA JA. 2015. The presence of Orius insidiosus Say (Hemiptera, Anthocoridae) in smallholding horticultural system with different designs, in Valle de Lerma, Salta, Argentina. Rev Fac Agron 114: 82-90.

PERVEZ A AND OMKAR A. 2003. Predation potential and handling time estimates of a generalist aphidophagous ladybird, Propylea dissecta. Biol Memoirs 29: 9-97.

RABASSE JM, TROUVE C, GERIAAM AND QUIGNOU A. 2001. Aphid pests of strawberry crops and their parasitoids in France. Mededelingen Faculteit Landbouwkundige en Toegepaste Biologische Wetenschappen Universiteit Gent 66: 293-301.

ROCCA M AND MESSELINK G. 2017. Combining lacewings and parasitoids for biological control of foxglove aphids in sweet pepper. J Appl Entomol 141: 402-410.

ROCCA M, RIZZO E, GRECO N AND SÁNCHEZ N. 2017. Intra and interspecific interactions between aphidophagous ladybirds: the role of prey in predator coexistence. Entomol Exp Appl 162: 284-292.

RONDON SI AND CANTLIFFE DJ. 2004. Chaetosiphon fragaefolii (Homoptera: Aphididae): a potential new pest in Florida? Fla Entomol 87: 612-615.

RONDON SI, CANTLIFFE DJ AND PRICE JF. 2004 The feeding behavior of the bigeyed bug, minute pirate bug, and pink spotted lady beetle relative to main strawberry pests. Environ Entomol 33: 1014-1019.

RONDON SI, CANTCLIFFE DJ AND PRICE JF. 2005. Population dynamics of the cotton aphid, Aphis gossypii (Homoptera: Aphididae), on strawberries grown under protected structure. Fla Entomol 88: 152-158.

THOMPSON JR, WETZEL S, KLERKS MM, VAŠKOVÁ D, SCHOEN CD, ŠPAK J AND JELKMANN W. 2003. Multiplex RT-PCR detection of four aphid-borne strawberry viruses in Fragaria spp. in combination with a plant mRNA specific internal control. J Virol Methods 111: 85-93.

TZANETAKIS IE AND MARTIN R. 2013. Expanding field of strawberry viruses which are important in North America. Int J Fruit Sci 13: 184-195.

VAN DRIESCHE RG AND HAUSCHILD K. 1987. Potential for increased use of biological control agents in small fruit crops in Massachusetts. Bull Mass Agric Exp Stn 718: 2234.

VAN LENTEREN JC. 2012. The state of commercial augmentative biological control: plenty of natural enemies, but a frustrating lack of uptake. BioControl 57: 1-20.

VENZON M, JANSSEN A AND SABELIS MW. 2002. Prey preference and reproductive success of the generalist predator Orius laevigatus. Oikos 97: 116-124. 